\title{
POLICY AND INSTITUTIONAL ENABLERS OF PUBLIC-PRIVATE PARTNERSHIPS IN THE ELECTRICITY SECTOR IN UGANDA: A MULTI-LEVEL AND PATH DEPENDENCE PERSPECTIVE
}

\begin{abstract}
Purpose: This paper explains the evident disproportionality in the levels of adoption of the modality of public-private partnerships (PPP) in Uganda by tracing the peculiar preconditions and enablers of the model's relative high adoption in the electricity sector.

Design/methodology/approach: Key conceptual suggestions from historical institutionalism (HI), critical juncture and path dependence are used to orient the data collection and analysis. The direct experiences and perceptions of key informants involved in policy, regulation and operations in the electricity sector are thematically analyzed.

Findings: The primacy of specific policy, institutional decisions, and actions sequentially undertaken at the international, national and sectorial levels in shaping the conceivability and possibility of PPP modality is foregrounded. In particular, international advisory for the changed role of the state and the government's subsequent decision to enact and reenact specific institutional frameworks at the national and sectorial levels created important disruptions to the status quo and paved a new and relatively stable institutional path conducive for private sector participation.

Implications: Theoretically, the paper demonstrates the ability and power of HI to support the exploration and framing of multilevel and path-dependent explanations of institutional development and policy adoption. Practically, suggestions in terms of policy, legal and regulatory enablers for the adoption of PPP are made to shape practitioners' decision making.

Originality/value: The importance of considering factor combinations and sequences in explaining the emergence, adoption, and proliferation of public policy instruments and phenomena is underscored. In addition, the discourse on PPPs is moved beyond rationalization to how to even-out their adoption (and subsequently the associated benefits) across sectors.
\end{abstract}

Key words: Public Private Partnerships, Historical Institutionalism, Uganda, Public Services

\section{INTRODUCTION}

The notion of private sector participation in public services provision and infrastructure development is now widely acknowledged (G. A. Hodge \& Greve, 2007; Kakabadse, Kakabadse, \& Summers, 2007; Mouraviev, 2013; Reeves, 2013). In addition to the traditional approaches of involving the private sector, such as contracting out, outsourcing and outright 
privatisation, in the development and/or routine provision of tax-paid public services, the modality of Public Private Partnerships (PPP) has gained more prominence in recent decades (Al-Saadi \& Abdou, 2016; Babatunde, Perera, Zhou, \& Udeaja, 2016; Dempsey, Burton, \& Selin, 2016; G. A. Hodge \& Greve, 2007; Slater, 2001).

PPPs are broadly understood as organisational arrangements whereby the public sector enters into long-term contractual agreement with private sector entities for the construction or management of public sector infrastructure facilities by the private sector entity, or the provision of services by the private sector entity on behalf of a public sector entity (Bovaird, 2010; Brinkerhoff \& Brinkerhoff, 2011; Grimsey \& Lewis, 2004b; Koppenjan, 2005). In many countries, PPPs have over the last two decades gained a standing as critical pillars of contemporary public management practice (G. Hodge \& Greve, 2010; Weihe, 2006; Wettenhall, 2010).

The diversity of arenas of the rationalisation of the modality is abounding. In particular, PPPs are justified as tools with which to address fiscal and inefficiency challenges (Landow \& Ebdon, 2012; Stafford \& Stapleton, 2017), the complexity or 'wickedness' of public problems (Brinkerhoff \& Brinkerhoff, 2011; Gray \& Stites, 2013; Pinkse \& Kolk, 2012), risk exposures (J. M. Bryson, Crosby, \& Stone, 2015; Currie \& Teague, 2015; Velotti, Botti, \& Vesci, 2012), and in some respects as a compromise approach to the parallelism in public services management ideologies (Bradford, 2003; Heuer, 2011; Vurro, Dacin, \& Perrini, 2010).

Arising mainly as a consequence of diverse rationales, since the early 2000s, many countries have strengthened practical efforts to launch PPPs as an important framework of public services and infrastructure provision (Bank, 2015; World Bank, 2017, 2018) in a wide range of economic and social sectors (Fischbacher \& Beaumont, 2003; Reeves \& Ryan, 2007; Yuan, Skibniewski, 
Li, \& Zheng, 2009). In last two decades, PPPs have been a major attraction in many developing countries, especially as they are seen as an opportunity to bridge endemic fiscal gaps (Bouman, Friperson, Gielen, \& Wilms, 2013; Bovis, 2013; Osei-Kyei \& Chan, 2017). Indeed, the World Bank's Private Participation in Infrastructure (PPI) database on low, lower-middle income and upper-middle income countries, for instance, indicates an increase in the number of PPI projects from 2,346 PPI between 1995 and 1999 to 6,792 PPI projects between 2000 and 2019. In the sub-Saharan region alone, the number of PPI projects that reached financial close rose to 472 from 102 in the years between 2000-2019 and 1995-1999, respectively (World Bank, 2019).

Notwithstanding the evidence of the increased number of PPI projects implemented in developing countries (DCs), the significant disproportionality in the spread across different sectors is evident (Lee, Xuehui, Quising, \& Villaruel, 2018; World Bank, 2019). For instance, of the 17 sectors profiled in the PPI database, the electricity subsector, in particular, appears to have generated more attention. Out of the 472 projects that reached financial close between the years 2000 and 2019, 271 are in the electricity sector. In Uganda, of the 25 projects that reached financial close in the same period, 22 - nearly $90 \%$ - of these projects are in the electricity sector. This places Uganda among the DCs with highest private participation in the electricity subsector relative to other sectors (World Bank, 2019).

While the extant literature appears to explain increasing private sector participation from a range of transaction cost economics and resource-based lenses, particularly focused on the fiscal constraints (Bovis, 2013; Boyer, 2016; Stafford \& Stapleton, 2017) and rampant public sector inefficiencies (Birner \& Wittmer, 2006; Hayllar, 2010), these explanations are challenged by the evident disproportionality in levels of private sector participation across sectors in DC contexts where constraints and inefficiencies indiscriminately apply. In other words, there appear to be 
specific enabling, yet also obscure, conditions for the peculiar increase in PPPs in the electricity sector. This paper posits that if the heralded benefits of PPP modality are to be reflected across different sectors of DC economies, the focus on spreading their adoption is central. In that regard, and as has been suggested elsewhere (see for e.g. John M Bryson, Crosby, \& Stone, 2006; Chen, 2010; Pittz \& Adler, 2016), it is critical to emphasise and move the discourse beyond the rationalisation of the modality to understand the antecedent preconditions and enablers in their contexts.

This paper draws on the key actor experiences to foreground important preconditions and enablers that explain the significant increase in PPPs in the electricity sector over the last two decades. This aim is operationalized by answering the following questions: What factors explain the increased adoption of PPP modality in the electricity sector? How can these be organized and sequenced? What implications for PPP policy, practice and future research can be derived? As is detailed later, the evidence suggests that the response to the international advisory on the need for a changed role of the state in public services provision, from provider to enabler, has generated disruptions to the public services delivery model status quo and paved a new and relatively stable institutional order conducive for private participation. The paper is of interest to public policy actors and PPP practitioners interested in extending the modality to other sectors and to researchers seeking perspectives on empirical context-specific and path-dependent enablers for PPPs.

The rest of this paper is organized as follows. Section two unpacks and rationalizes the key notions of historical institutionalism as the theoretical frame of reference. In particular, critical junctures and path dependence are emphasized as orienting concepts for the analysis of evidence and the discussion of findings. Section three identifies and explains the methods and materials 
used, specifically elaborating protocols for the collation and analysis of the empirical evidence. Section four presents the key findings and focuses on identifying and illustrating the important institutional decisions and actions undertaken, sequentially organized in three levels. In section five, a discussion of the findings in the context of applied theory and extant research is undertaken, along with delineation of the key implications followed by the conclusion.

\section{THE THEORETICAL PERSPECTIVE}

Historical institutionalism (HI) provides useful insights into understanding the proliferating phenomenon of private sector participation in public services provision, especially the adoption of the modality PPPs. HI is one of the three strands of new institutionalism, alongside rational choice institutionalism and sociological institutionalism (Campbell \& Pedersen, 2001; Hall \& Taylor, 1996). HI places primacy on the empirical and historical perspective in the study of institutions, purposed on explaining individual and collective behavior (Campbell \& Pedersen, 2001).

HI spreads the conception of institutions beyond the realm of organizations to incorporate formal and informal sets of rules, procedures, policy legacies, norms and conventions that are embedded in the organizational structure of polity (Hall \& Taylor, 1996). While HI is viewed as 'a rather loose collection of writings by authors that tend to mix elements of rationalistic and constructivist explanations - or the "calculus" versus the "cultural” approach' (Immergut, 2006), the framework's potency for this study lies in its emphasis on the constraints that institutional structures impose on social and political behavior (Hall \& Taylor, 1996; Steinmo, 2008; Thelen, 2002). In particular, HI sees policy decisions as being historically constructed and institutionally 
embedded in a system composed of interacting parts that shape the social identities and political strategies of individual and collective actors over time.

As an analytical approach, $\mathrm{HI}$ is associated with two important concepts that are particularly useful for our analysis in this investigation. The first concept is 'path dependence', which draws on institutional economics and postulates institutional change to be heavily constrained by past policy choices (Steinmo, 2008; Thelen, 1999). The second concept is 'critical juncture', according to which important shocks and crises can disrupt the institutional status quo and trigger fundamental changes before a new, relatively stable order emerges in the form of a new historical and institutional path (Campbell \& Pedersen, 2001; Capoccia \& Kelemen, 2007; Hall \& Taylor, 1996). In other words, critical junctures represent turning points that are shown to have established important institutional parameters that subsequently shape what is politically possible, even conceivable. This means that during critical junctures, institutional arrangements may adopt a new path that is generally hard to alter because it is embedded in relatively stable rules, practices, and vested interests (Capoccia \& Kelemen, 2007; Immergut, 2006). Critical junctures thus become potential starting points for path-dependent processes.

Placing emphasis on continuity and historical contingency in institutional development as the conceptual premises, path dependence and critical junctures emerge as powerful analytical tools for uncovering concerns relating to the origins and drivers of important policy arrangements and modalities, such as PPPs, in a particular context. This study draws on these concepts to orient the analysis of empirical evidence. As is later demonstrated, HI provides unique insights into how specific moments and the decisions and actions of different actors at the international, national and sectorial levels interacted to create uniquely conducive institutional conditions that made PPPs conceivable and possible in Uganda's electricity sector. 


\section{MATERIALS AND METHODS}

This case study investigation is based on a qualitative research paradigm. As a method of inquiry, a case study denotes an intensive investigation into a single case (bounded system) or set of cases (multiple bounded systems with the intention to deeply explore and understand complex social phenomena (Creswell, Hanson, Clark Plano, \& Morales, 2007; Yin, 2011). The arrangement of private sector participation in public services provision, particularly through PPPs, is very complex owing to a myriad of contextual peculiarities. Some of these relate to differences in partner perspectives, interests and preferences, compounded by the varieties of actor constellations that are foregrounded at different phases (Hertogh \& Westerveld, 2010; Ward \& Chapman, 2008). Indeed, as Figure 1 portrays, the sector's complexity in the case of Uganda is evident in the multiplicity of actors in the depicted electricity service value chain.

In addition, case-based investigations are particularly helpful for explaining phenomena with theories (Levy, 2008; Yin, 2011) as well as for in-depth historical and institutional assessments, both of which fit the intention, design and context of this investigation.

This investigation is based on primary and secondary data. The primary data were obtained from face-to-face interviews with 28 key individuals (a) in the government, particularly in policy work within the Ministry of Energy and Mineral Development and other government departments like the Ministry of Finance and Economic Development, (b) national legislation, (c) electricity sector regulation, (d) participating public and private sector companies, and (e) international consultants familiar with the sector and modality, as reflected in the appendix 1 of the supplementary material. 
Given the historical approach and the empirical context of this study, a snowballing technique (Browne, 2005; Miles \& Huberman, 1994) was considered more relevant to collate the data. Specifically, in light of limited experiences with the PPP modality in Uganda and the commercial confidentiality associated with PPP transactions, snowballing presented the best option to reach participants. Other PPP scholars studying similar contexts have found this technique equally useful for its ability to allow researchers to harness existing trust and relationships among informants (see, for example, Beyene, 2014; Chung, 2009; Opawole \& Jagboro, 2017). The interview data were complemented by a review of a range of exclusively availed and publicly available documents listed in appendix 2 of the supplementary material. The ascertainment and sourcing of the relevant documents were conducted alongside the interviews with informants, who were asked to suggest and/or avail any informative documentation.

All the audio files were uploaded to NVIVO qualitative data analysis software, where the transcription was conducted and the text data subsequently analyzed. Content analysis was conducted to identify high-level concepts in the data that could offer key ideas and actionable insights. This analysis involved the careful, detailed, systematic examination and interpretation of the interview and documentary data to identify patterns, themes, biases, and meanings (Hsieh \& Shannon, 2005). As delineated earlier, the analysis was oriented by the concepts of critical junctures and path dependence from the applied theoretical lens. The data coding was performed in phases. In the first phase, important segments of data indicating or relating to decisions and actions undertaken were coded. In the second phase, data-grounded themes were generated accordingly through a reinterpretation of coded decisions and decision groups (see appendix 3 in the supplementary material for the codebook). These categories and corresponding decisions are presented and illustrated in the findings. 


\section{National and Sectorial Context}

The involvement of the private sector in the early stages of the economic liberalization agenda mainly involved the outright privatization of formerly government-owned business entities. By 1986, Uganda had over 130 government business enterprises. At the urging of the World Bank and the International Monetary Fund (IMF), by June 30, 2011, the government had conducted 95 sell-off transactions and 39 liquidations (Uganda News Releases, 2015). Earlier on, in order to enable the process, the Public Enterprises Reform and Divestiture Act (PERD) of 1993 was enacted.

The PERD Act created three classes of public enterprises and prescribed the modality for private sector participation. In the first class, the state is required to retain $100 \%$ shareholding in these enterprises. This class includes seven enterprises, some of which are the Civil Aviation Authority, Cotton Development Authority, and National Social Security Fund. Added to this class were any regulatory agencies formed as a result of sectorial reforms. In the second class, the Act stipulated that the government retain majority shareholding. Some examples in this class of 14 enterprises include Uganda Electricity Board (which is the main sector focus of this study), Housing Finance Company of Uganda Limited, National Medical Stores, and National Water and Sewerage Corporation. In the third class, 88 enterprises were to be divested following the prescribed legal guidelines. The third-class enterprises were mainly divested through sale of assets, share sale, joint ventures and pre-emptive rights. The others were disposed of through other approaches, such as public offerings, concessions, auctions, debt equity swaps and repossessions (Bennell, 1997; Tangri, 1999).

As this paper later illustrates, these policy and institutional decisions arguably set the initial tone for the mutual interest and prolonged interaction between the government and the private sector 
in an institutionalized and/or contractually binding way, creating part of the foundation for PPPs in Uganda.

The cross-sectorial institutional setup of the PERD Act notwithstanding, the disproportionate proliferation of the PPP modality in the electricity sector relative to others following the PERD Act is the explanatory focus of this paper. As highlighted, the value chain components open to private participation, that is, electricity generation and distribution, account for 22 of the 25 PPP projects (24 active and 1 distressed) reported currently the World Bank Private Participation in Infrastructure (PPI) database. The others are in the transport, water and telecommunications sectors (World Bank, 2017, 2019).

\section{EMPIRICAL FINDINGS}

Our analysis of the evidence reveals the primacy and sequence of a number of factors and decisions that were instrumental in making the adoption of PPPs in the electricity sector in Uganda conceivable and possible. We present and illustrate these factors in three important thematic categories, namely (a) the influence of international agenda for liberalization and deregulation, (b) the national public sector reform process, and (c) the specific electricity sector institutional reforms.

\section{The International Drive for Liberalization, Deregulation and Privatization}

The interview indicates that the fundamental influence of the international agenda for liberalization and the proliferating drive for the deregulation and privatization provided an important foundation for the eventual adoption of PPPs in the electricity sector. In this regard, the instrumental role played by international and multilateral lending agencies in shaping the decisions processes at the national level was emphasized by interviewees (Interview 1, 2018; 
Interview 3, 2018; Interview 8, 2018; Interview 10, 2018). In particular, the ideological push for the involvement of the private sector was strong, which most governments in developing countries resist (Interview 8, 2018; Interview 10, 2018; Interview 13, 2018). As an interviewee observed in the following quote:

It was an ideological drive; you know, when the ocean comes even if you do not want the water will come, yes. So the things started coming so government said OK. They first resisted and later they said OK. (Interview 13, 2018)

The interviewees simultaneously pointed to the nature of the conditions attached. In particular, the interviewees noted that the international lending agencies set an inevitable direction towards the participation of the private sector (Interview 8, 2018; Interview 10, 2018; Interview 14, 2018). As one interviewee specifically observed in the following quote, attaching government borrowing to the involvement of the private sector was particularly significant.

It (Government) would not borrow. You see the world economic thinking is shaped in certain places if they say this is what can work, everybody has to follow that. Now the idea of government running some of these institutions, they found it offensive, the western money markets, the government was being accused of being inefficient, leading to loss of colossal sums of money and so on. In order to cure this, everything should be passed on the private sector (Interview 8, 2018).

Similarly, the interviewees pointed to decisions by political leaders to align with the international trends on private sector involvement, which subsequently raised the national-level momentum (Interview 14, 2018). In particular, there arose principal support from the highest levels of political leadership for private sector involvement and for the changed role of the state, which increased the 
momentum and generated the urgency for the involvement of the private sector in government business (Interview 10, 2018; Interview 14, 2018; Interview 16, 2018; Interview 17, 2018). As the excerpt below suggests, the political leadership's embracing the idea of privatization set an important pace at the national level.

...we were a bit ahead because of the World Bank supported programme, on liberalization and privatization, so we went head on. And the President (President of the Republic of Uganda) at the time had a political will. The President actually was at the forefront of the programme. So, we went for privatization and typically it was just to give everything that you can to the private sector, let government get out of business........... I remember there was even a time when the President said, I don't care, if it means handing the ministries (government ministries) to the private sector, I will do it (Interview 14, 2018)

As the above illustrates, the advent of liberalization, deregulation and privatization across the globe appears to have set the pace and the initial drive for the involvement of the private sector in Uganda's infrastructure. As the interviewees suggested, this set the policy foundation for sharing the public mandate between the private and public sector. This policy direction would later be structured and enabled through significant institutional sector reform processes at the national level.

\section{The Public Sector Institutional Reform Processes}

The evidence also points to the set of instrumental decisions under the public sector reform processes that set a broader institutional foundation for private sector participation. At the national level, the different sets of decisions consolidated under the Public Enterprises Reform and Divestiture Act of 1993 were instrumental ("Public Enterprises Reform and Divestiture Act," 
1993). In particular, an instructive role was played, on the one hand, by the decision to map and classify the enterprises and, on the other hand, the definition of the government stake and shareholding in those enterprises (see "Public Enterprises Reform and Divestiture Act," 1993). The quote below from the former head of the Privatization Unit provides an illustration.

The PERD Act classified the categories where at that point in time we were tossing around where government would retain some shareholding and where government would concede the entire holding with the private sector and where government was set to retain majority shareholding. Now, the thinking was beginning to formulate at that time that there are certain segment of businesses or businesses that you cannot just hand over to the private sector, so the awareness came into play (Interview 14, 2018).

Specifically, it appears the enterprise categorization as was enshrined in the law helped to foretell and lock in the modes of involvement of the private sector. In that way, the decision paved the way for the legal conceivability and possibility of private sector involvement in government business. At the national level, the application of the institutional framework, in this case the PERD Act, would have maintained the private participation within the classified enterprises and only in the modes envisaged. However, the later sector-specific decisions and actions appear to have generated more impetus within the electricity sector.

\section{Electricity Sector Institutional Reforms}

The third set of decisional drivers is made at the sector level and is particularly important in this case. Broadly, the interviewees pointed to the centrality of the decisions contained in the revisions and amendments made to the Electricity Act of 1999 in setting up more and peculiar enabling conditions for private sector involvement (Interview 3, 2018; Interview 8, 2018; 
Interview 9, 2018; Interview 12, 2018; Interview 23, 2018; Interview 24, 2018). As this quote, for instance, prefaces, the revisions opened up more possibility for private participation, albeit within a prior specific participation modality.

So, (the) decision to amend the electricity act was taken and in 1999 a new law, a new statute, was put in place, the Electricity Act of 1999. And essentially this opened up the power sector to independent power producers (and) to a number of other operators that were not necessarily government (Interview 8, 2018).

Specifically, two important decisions and actions are underscored by the interview evidence: the establishment of an independent regulatory authority and the unbundling of the sector. The evidence highlights that the decision to establish an independent regulatory authority importantly provided potential private sector actors with the necessary confidence and assurance of the protection of their interests. As the following excerpt specifically illuminates, in the absence of prior experience with the involvement of private actors in the electricity sector, it appears that the existence of an independent regulator was a necessary precondition.

.....in that framework there were some conditionality which the private sector had provided, they said if you want us to come in the energy space, you must have an Energy Act repealed and amended so they (Government) amended it. They brought in the regulator, they (private sector) said we want somebody to come in and regulate the energy sector because by then it was Uganda Electricity Board (UEB), U.E.B was the regulator, generator, and was the supplier. So they (private sector) said they want somebody who oversees the sector and somebody who is going to provide the tariff, to provide a license, and all this sanity in the energy sector (Interview 13, 2018). 
Similarly, putting in place an independent regulatory authority was seen as a necessary link to regulate the relationship between the private operator and service users, who are the citizens (Interview 3, 2018; Interview 4, 2018; Interview 9, 2018). Again, with the limited experience of the private sector in public services provision, the modality was therefore new to many stakeholders, including the citizenry. As result, the management of public opinion in the context of such a new phenomenon appears to be one of the preconditions addressed by the regulation (Interview 9, 2018; Interview 27, 2018). In addition, key elements of the interaction would be framed by the independent regulation and would thus provide the necessary protection for the private providers of the service and to other stakeholders, as the two following excerpts directly illuminate.

So, government took a decision to separate the regulation from day-to-day running of the business but they left the policy in the hands of Ministry of Energy and Mineral Development (Interview 8, 2018).

Then they (government) said we shall put in a regulator to oversee you guys, your operation, pricing and to protect the interest of the customer and public (Interview 3, 2018).

Secondly, the decision to unbundle the sector appears to have been central to enabling the involvement of the private actors. Separating the key aspects of the sector's vertically integrated value chain into distinct business units (generation, transmission, and distribution), as well as the subsequent decision to retain the transmission segment under complete government mandate, was noted by many interviewees as an important decision that made the involvement of the 
private sector both conceivable and possible (Interview 3, 2018; Interview 8, 2018; Interview 12, 2018; Interview 14, 2018; Interview 21, 2018). As one interviewee explained:

First of all, remove the vertical integration and split it (electricity service value chain) into units and then look at which business units the private sector would take. ..... (Electricity) generation is easy, distribution is not so easy but it is also easier than transmission. And the people (private sector) that you bring in to do the other two (generation and transmission) need a middle man who is trusted by government that that is Uganda Electricity Transmission Company Limited (UETC) (Interview 21, 2018).

Specifically, the evidence suggests more enabling circumstances created by the unbundling decision by way of reducing the complexity of the electricity service value chain, facilitating the ascertainment of commercial viability and the clarification of critical policy interest aspects of the electricity service value chain (Interview 3, 2018; Interview 12, 2018; Interview 13, 2018). The evidence specifically indicates that by creating the business unit distinctiveness, the necessary assessment of each unit's possible attractiveness, feasibility and viability for private sector involvement was enabled. As a government minister explained below:

And it (the electricity sector) was vertically integrated, generation, transmission and distribution (the) same entity. But in order now to get private people to come to the sector, we had to unbundle, transmission remained government. Transmission remained government because we thought it was like a highway. Now distribution was privatized so the private people came in to run this formerly vertically integrated entity (Interview 12, 2018). 
In all, the evidence points to the centrality of a specific sequence of decisions and actions that preluded the involvement of private actors. These decisions and actions created alterations to the established institutional status quo involving direct electricity service delivery by the government and through a vertically integrated organizational structure under the former establishment of the Uganda Electricity Board. The following section discusses some of the decisions and actions relating to the three sequential phases at the international, national and sectorial levels in light of the theoretical and extant research.

\section{DISCUSSION OF THE FINDINGS OF THE POLICY AND INSTITUTIONAL ENABLERS OF PPPS}

This analysis has delineated the important policy and institutional explanations for the observed proliferation of the PPP modality in the electricity sector in Uganda. Based on key notions from the HI perspective, the analysis has underscored the primacy of three important sequential phases and the attendant ideological and institutions-focused decisions and actions. The emphasis here is on key decisions that created important disruptions to the direct public delivery of electricity, thereby laying an important institutional foundation for the PPP modality in the sector.

Firstly, the evidence has pointed to the influence of international trends and the shift towards to the economic liberalization, deregulation and privatization that provided an overarching context for the involvement of the private sector in public services in Uganda. In this case, it particularly appears that the decision by the international lending agencies to condition government borrowing on the government working with the private sector incentivized political leaders' attitudes and the subsequent government policy on the involvement of the private sector. 
Consistent with the premises of HI, the finding suggests that such decisions by the multilateral lenders closed off alternative options, particularly the option to continue with the direct public services provision by the government, and simultaneously established a new institutional path for the involvement of the private sector in public services provision. The context thus created mirrors the assumption of path dependence, whereby in the course of institutional development, self-triggering and self-reinforcing processes beyond the control of individuals or individual organizations, irrespective of their level of influence, are set in motion. This mirrors a fairly recent observation in which the sustainability of trans-border partnerships was found to be dependent on major rules governing the system of cooperation (Szmigiel-Rawska, 2016).

Similarly, the influence of multilateral agencies in driving private sector participation is not an isolated finding of this investigation. The pressures on developing countries from international financial institutions, such as the World Bank and the International Monetary Fund, to shift to an efficient system, to an enabler role of the government and to adopt the principles of market liberalization and privatization abound (Hughes, 1998; Jamali, 2004; Peters, 2000). Specific references, for instance, have often been made to financial assistance being conditioned for governments in developing countries, changing the focus and orientation of governing from direct involvement and intervention to a role revolving around partnership and facilitation (Hughes, 1998; P. Lawrence, 2002). Indeed, the broader and longstanding attribution of PPP evolution over the past decades has been associated with donor-country development thinking as a central component of foreign policy toward developing countries (Bouman et al., 2013; P. Lawrence, 2002; T. B. Lawrence, Phillips, \& Hardy, 1999; Mitchell-Weaver \& Manning, 1991)

Secondly, the legal and policy adjustments appear to have provided a fundamental institutional setup at the national level. Although it is evident that the ideological premises at the international 
level, in the preceding discussion, rendered huge impetus for private sector participation, the enactment of the Public Enterprise Reform and Divesture (PERD) Act in 1993 actively enabled the ideals at the national level. It would be difficult to envisage a starting point for the operationalization of any form of private participation, in the context of long-standing direct public services provision of public services, in the absence of an enabling institutional framework.

In this case, the instructive nature of the PERD Act is central as it classified the public assets and defined the extent of government ownership and involvement in management. The enactment of the Act importantly shaped and simplified the actions of policy actors. As has been elaborated earlier, it is clearly traceable that the decision to enact such an instructive legal framework heightened the general possibility of private sector participation at the national level.

Thirdly, at the sector level, the decision to unbundle the vertically integrated sector into three distinct business units of generation, transmission and distribution proved significantly instructive. By reducing the complexity of the sector and clarifying the services value chain, the government of Uganda enabled the private sector to more clearly assess the commercial viability of investing in the sector. While it appears that the sector was generally understood to be inefficiently operated, it was not possible to clearly understand the more ineffective phases of the value chain. As such, it was not possible to determine what needed to be done by the different stakeholders to improve efficiency and effectiveness in the sector.

Ironically, bundling key components of the service or infrastructure value chain has specifically been a hallmark of PPPs' engagement, whereby the private partner takes responsibility for the entire service or infrastructure value chain (Boyer, 2016; Grimsey \& Lewis, 2004a; Hueskes, 
Verhoest, \& Block, 2017). However, this case has instead revealed the primacy of unbundling the service value chain as an important precursor to private sector participation. While this observation appears to contradict a widely acknowledged character trait of PPP engagement, it is consistent with emerging observations cautioning against bundling. For instance, a fairly recent study of the Flemish Sports Infrastructure Program (Van den Hurk \& Verhoest, 2015) warned against opting for 'big bang' bundled programs as these entail more significant risks and tend to be more difficult to co-ordinate and manage. Consistent with our observation in this paper, the study concludes that in the context of a complex project, it is less risky to opt for a cautious, incremental approach, with a simple governance structure.

Similarly, while the notion of deregulation is one of the overriding premises for the involvement of the private sector, the particular findings of this study also suggest the primacy of its converse, regulation, as a precondition for private sector involvement in public services provision. In particular, the mutual requirement revealed in this case for the establishment of an independent regulatory authority by both the government and prospective private sector investors makes two important suggestions. From the public sector perspective, it suggests the need to guard against private interest capture and possible collusion against public interest. On the other hand, the private sector expects that the independent regulation moderates the possible public interest capture and power play. In the context of PPPs characterized by information and experience asymmetry between partners (Boyer, 2016), independent regulation appears to enable rather than disable the model's adoption, as the reality of this case has illustrated.

\section{Revisiting Historical Institutionalism, Policy, and Research Implications}


The findings of this study reinforce the important premises of $\mathrm{HI}$ as an analytical framework as they underscore the primacy of important occurrences and the significance of decisional sequences and timing. In this way, the findings demonstrate the ability and power of $\mathrm{HI}$ to support exploration, framing multilevel and path-dependent explanations for institutional development and policy adoption.

From a practical perspective, the study has helped to identify the important policy, legal and regulatory enablers for the adoption of the PPP modality in the electricity sector. In so doing, this paper generates important clarity between two strands of explanation for PPP proliferation in the sector. In particular, this paper creates a necessary perspective that distinguishes the more dominant narrative focused on the rationale for PPPs - emphasizing the theoretical benefits of partnership on the one hand - and enablers of PPPs - emphasizing the important preconditions and facilitative factors of PPP modality on the other hand.

As noted earlier, despite PPP proliferation, this distinction has been underemphasized, and sometimes conflated, with the focus on understanding specific and context-specific enablers largely relegated in the extant discourse - except for a few conceptual and overarching studies focused on cross-sector collaborations (e.g. John M Bryson et al., 2006), those drawing on broader considerations of PPP success and failure (e.g. Jamali, 2004), and others drawing on influence of exceptional natural circumstances (e.g. Simo \& Bies, 2007). In addition, since enablers, as opposed to rationalizations, are context specific, it is less likely that inferring and applying experiences from contexts shaped by different institutional arrangements would be appropriate. 
While the findings of the study have insightfully provided important historical and multilevel institutional drivers to explain the evident proliferation of the PPP modality in the electricity sector in Uganda, it is important to note that this study is not without limitations. Firstly, we acknowledge that the use of the notion of private sector participation and the concept of PPP may elicit confusion as they appear to be used interchangeably. While PPP is indeed a form of private sector participation, not every form of private sector participation is a PPP. For instance, this paper does not consider the traditional contracting out, outsourcing and privatization as PPPs, although they may often be confused as such. The deliberate attempts to clarify this distinction notwithstanding, it is an acknowledgement in this paper that some of the interviewees particularly used the concept of privatization instead of PPP.

Similarly, while the identification of context-specific variables and patterns undertaken in this study is important, some may view this as detracting from the broader task of discovering the general drivers for PPP adoption that hold across time and space. In particular, first, this study is cognizant that by focusing on the electricity sector, it is not possible to directly infer that similar institutional factors could elicit an identical impact in other sectors of the economy in Uganda or elsewhere. Secondly, the evidence has been analyzed from a peculiar theoretical lens, namely historical institutionalism. Although we have provided an important rationale for this decision, the possibility remains that potentially important explanations for the proliferation of PPP in the sector and country may have been left out.

Thirdly, the interviews required retrospection from interviewees, some for as long as 14 years. Although these experiences are corroborated by publicly available documentary evidence, they may have been affected by any memory losses. Finally, while this qualitative study has helped to map the important drivers, it was not possible to determine the relative extents to which the 
various drivers impacted on the decision to adopt the modality of PPPs in the sector. In other words, the levels of importance of the different factors remain unclear.

In light of these methodological drawbacks, a sequential mixed study may be useful. Qualitative meta-synthesis of extant empirical evidence would delineate drivers that transcend historical or regional contexts, and a survey of these drivers among the policy actors would help determine their relative influence. It may also be useful to explore the nature of the influence (if any) that the nascent national legislation, specifically the enactment of the PPP Act in 2015, has had on adoption of the PPP model in terms of private sector participation within and/or outside the electricity sector. In particular, it would be interesting to see whether the enactment of the PPP Act is facilitating an even greater spread of PPPs across sectors than has been witnessed over the last two decades.

\section{CONCLUSION}

In a nutshell, this paper foreshadowed the multilevel and path-dependent institutional explanations for the increased adoption of the PPPs in Uganda's electricity sector. Based on the evidence, this paper posits that at the national level, the drive towards private sector participation in public infrastructure and services was highly influenced by the domestication of the neoliberal ideals on the changed role of the state through the enactment of different sets of institutional frameworks at the national and sectorial levels. In turn, the new sets of institutional framework at the sectorial level disrupted the institutional status quo by closing off the option of direct (traditional) provision by public agencies, thus establishing a stable path to various modes of private participation, most evidently the PPP modality, in the sector. 


\section{Notes:}

1. Uganda first developed a national PPP policy in 2010, which culminated in the enactment of the PPP Act 2015. Both the policy and the Act had no retrospective effect and are, in practice to date, only an alternative institutional arrangement for engagement with the private sector.

2. Prior to the enactment of the PPP Act, all interactions between the government and public sector agencies and private sector entities for the provision of public services and/or management and operation of public assets were governed by the Public Enterprise Reform (PERD) Act 1993 and Public Procurement and Disposal Public Asset (PPDA) Act 2003.

3. The PERD and PPPA laws were complemented by the specific sector laws and regulations, such as the Electricity Act 1999 for the electricity sector, and any others where they exist.

4. The colloquial use of the concept of privatization in reference to any form of private sector participation in services provision and public asset operations and management is common in Uganda. 


\section{Notes: Interviewee list}

Interview 1 (2018, June). [Semi-structured Interview]. Oral face to face.

Interview 3 (2018, June). [Semi structured interview with Private partner reprsentative in the Electricity Distribution Concession in Uganda].

Interview 4 (2018, April). [Semi structured Interview with representative of Private Partner in the Electricity Distribution concession in Uganda]. Oral face to face.

Interview 8 (2018, May). [Semi structured interview with an official in Governnment department knowledgable about the Electricity distribution concession]. Oral.

Interview 9 (2018, June). [Semi structured interview with an official in Governnment department knowledgable about the Electricity distribution concession]. Oral.

Interview 10 (2018, July). [Semi structured interview with an official in Governnment department knowledgable about the Electricity distribution concession]. Oral.

Interview 12 (2018, April). [Semi structured interview with an official in Governnment department knowledgable about the Electricity distribution concession]. Oral.

Interview 13 (2018, May). [Semi structured interview with an official in Governnment department knowledgable about the Electricity distribution concession]. Oral.

Interview 14 (2018, May). [Semi structured interview with an official in Governnment department knowledgable about the Electricity distribution concession]. Oral.

Interview 16 (2018, May). [Semi structured interview with an official in Governnment department knowledgable about the Electricity distribution concession]. Oral.

Interview 17 (2018, April). [Semi structured interview with an official in Governnment department knowledgable about the Electricity distribution concession]. Oral

Interview 21 (2018, June). [Semi-structured Interview with an official from the Electricity Regulatory Authority about the UMEME - UEDCL Electricity Distribution Concession]. Oral.

Interview 23 (2018, April). [Semi-structured Interview with an official from the Electricity Regulatory Authority about the UMEME - UEDCL Electricity Distribution Concession]. Oral.

Interview 24 (2018, May). [Semi-structured Interview with an official from the Electricity Regulatory Authority about the UMEME - UEDCL Electricity Distribution Concession]. Oral.

Interview 27 (2018, May). [Semi-structured Interview with an official from the Electricity Regulatory Authority about the UMEME - UEDCL Electricity Distribution Concession]. Oral. 


\section{REFERENCES}

Al-Saadi, R., \& Abdou, A. (2016). Factors critical for the success of public-private partnerships in UAE infrastructure projects: experts' perception. International Journal of Construction Management, 16(3), 234-248.

Babatunde, S. O., Perera, S., Zhou, L., \& Udeaja, C. (2016). Stakeholder perceptions on critical success factors for public-private partnership projects in Nigeria. Built Environment Project and Asset Management, 6(1), 74-91.

Bank, W. (2015). PPIAF Annual Report. Retrieved from

Bennell, P. (1997). Privatization in sub-Saharan Africa: Progress and prospects during the 1990s. World development, 25(11), 1785-1803.

Beyene, T. T. (2014). Factors for implementing public-private partnership (PPP) in the development process: Stakeholders' perspective from Ethiopia. International Journal of Science and Research, 3(3), 792-797.

Birner, R., \& Wittmer, H. (2006). Better public sector governance through partnership with the private sector and civil society: the case of Guatemala's forest administration. International Review of Administrative Sciences, 72(4), 459-472. doi:10.1177/0020852306070077

Bouman, S., Friperson, R., Gielen, M., \& Wilms, P. (2013). Public-Private Partnerships in developing countries. IOB Evaluations (Netherlands) eng no. 378.

Bovaird, T. (2010). A brief intellectual history of the Public-Private partnership movement. In G. A. Hodge, C. Greve, \& A. E. Boardman (Eds.), International Handbook on Public-Private Partnerships. United Kingdom: Edward Elgar Publishing Limited.

Bovis, C. (2013). Public-private partnerships in the European union: Routledge.

Boyer, E. J. (2016). Identifying a Knowledge Management Approach for Public-Private Partnerships. Public Performance \& Management Review, 40(1), 158-180. doi:10.1080/15309576.2016.1204928

Bradford, N. (2003). Public-private partnership? Shifting paradigms of economic governance in Ontario. Canadian Journal of Political Science-Revue Canadienne De Science Politique, 36(5), 1005-1033.

Brinkerhoff, D. W., \& Brinkerhoff, J. M. (2011). Public-private partnerships: Perspectives on purposes, publicness, and good governance. Public Administration and Development, 31(1), 2-14. doi:10.1002/pad.584

Browne, K. (2005). Snowball sampling: using social networks to research non-heterosexual women. International journal of social research methodology, 8(1), 47-60.

Bryson, J. M., Crosby, B. C., \& Stone, M. M. (2006). The design and implementation of Cross-Sector collaborations: Propositions from the literature. Public Administration Review, 66(s1), 44-55.

Bryson, J. M., Crosby, B. C., \& Stone, M. M. (2015). Designing and Implementing Cross-Sector Collaborations: Needed and Challenging. Public Administration Review, 75(5), 647-663. doi:10.1111/puar.12432

Campbell, J. L., \& Pedersen, O. K. (2001). The rise of neoliberalism and institutional analysis: Princeton University Press.

Capoccia, G., \& Kelemen, R. D. (2007). The study of critical junctures: Theory, narrative, and counterfactuals in historical institutionalism. World politics, 59(3), 341-369.

Chen, B. (2010). Antecedents or Processes? Determinants of Perceived Effectiveness of Interorganizational Collaborations for Public Service Delivery. International Public Management Journal, 13(4), 381-407. doi:10.1080/10967494.2010.524836

Chung, D. (2009). Developing an analytical framework for analysing and assessing public-private partnerships: a hospital case study. The Economic and Labour Relations Review, 19(2), 69-90. 
Creswell, J. W., Hanson, W. E., Clark Plano, V. L., \& Morales, A. (2007). Qualitative research designs: Selection and implementation. The counseling psychologist, 35(2), 236-264.

Currie, D., \& Teague, P. (2015). Conflict Management in Public-Private Partnerships: The Case of the London Underground. Negotiation Journal, 31(3), 237-266.

Dempsey, N., Burton, M., \& Selin, J. (2016). Contracting out parks and roads maintenance in England. International Journal of Public Sector Management, 29(5), 441-456.

Fischbacher, M., \& Beaumont, P. (2003). PFI, public-private partnerships and the neglected importance of process: Stakeholders and the employment dimension. Public Money and Management, 23(3), 171-176.

Gray, B., \& Stites, J. P. (2013). Sustainability through partnerships. Capitalizing on collaboration. Network for business sustainability, case study.

Grimsey, D., \& Lewis, M. K. (2004a). Discount debates: Rates, risk, uncertainty and value for money in PPPs. Melbourne University Private,

Grimsey, D., \& Lewis, M. K. (2004b). The governance of contractual relationships in public-private partnerships. Journal of corporate citizenship(15), 91-109.

Hall, P. A., \& Taylor, R. C. (1996). Political science and the three new institutionalisms. Political studies, 44(5), 936-957.

Hayllar, M. R. (2010). Public-Private Partnerships in Hong Kong: Good Governance - The Essential Missing Ingredient?1. Australian Journal of Public Administration, 69, S99-S119. doi:10.1111/j.1467-8500.2010.00675.x

Hertogh, M., \& Westerveld, E. (2010). Playing with Complexity. Management and organisation of large infrastructure projects.

Heuer, M. (2011). Ecosystem Cross-Sector Collaboration: Conceptualizing an Adaptive Approach to Sustainability Governance. Business Strategy and the Environment, 20(4), 211-221. doi:10.1002/bse.673

Hodge, G., \& Greve, C. (2010). Public-Private Partnerships: Governance Scheme or Language Game? Australian Journal of Public Administration, 69, S8-S22. doi:10.1111/j.1467-8500.2009.00659.x

Hodge, G. A., \& Greve, C. (2007). Public-private partnerships: an international performance review. Public administration review, 67(3), 545-558.

Hsieh, H.-F., \& Shannon, S. E. (2005). Three approaches to qualitative content analysis. Qualitative health research, 15(9), 1277-1288.

Hueskes, M., Verhoest, K., \& Block, T. (2017). Governing public-private partnerships for sustainability An analysis of procurement and governance practices of PPP infrastructure projects. International Journal of Project Management, 35(6), 1184-1195. doi:10.1016/j.ijproman.2017.02.020

Hughes, O. E. (1998). New public management. In Public Management and Administration (pp. 52-80): Springer.

Immergut, E. M. (2006). Institutional constraints. The Oxford handbook of public policy.

Jamali, D. (2004). Success and failure mechanisms of public private partnerships (PPPs) in developing countries. International Journal of Public Sector Management, 17(5), 414-430. doi:10.1108/09513550410546598

Kakabadse, N. K., Kakabadse, A. P., \& Summers, N. (2007). Effectiveness of private finance initiatives (PFI): study of private financing for the provision of capital assets for schools. Public Administration and Development: The International Journal of Management Research and Practice, 27(1), 49-61.

Koppenjan, J. (2005). The Formation of Public-Private Partnerships: Lessons from Nine Transport Infrastructure Projects in The Netherlands. Public Administration, 83(1), 135-157. 
Landow, P., \& Ebdon, C. (2012). PUBLIC-PRIVATE PARTNERSHIPS, PUBLIC AUTHORITIES, AND DEMOCRATIC GOVERNANCE. Public Performance \& Management Review, 35(4), 727-752. doi:10.2753/pmr1530-9576350408

Lawrence, P. (2002). Structural Adjustment and Sub Saharan Africa. In K. Colin, R. Clarke, \& C. Polidano (Eds.), Handbook on Development Policy and Management. United Kingdom: Edward Elgar Publishing Limited.

Lawrence, T. B., Phillips, N., \& Hardy, C. (1999). Watching whale watching: Exploring the discursive foundations of collaborative relationships. The Journal of Applied Behavioral Science, 35(4), 479502.

Lee, M., Xuehui, H., Quising, P., \& Villaruel, M. (2018). Hazard Analysis on Public-Private Partnership Projects in Developing Asia Retrieved from Philippines:

Levy, J. S. (2008). Case studies: Types, designs, and logics of inference. Conflict management and peace science, 25(1), 1-18.

Miles, M. B., \& Huberman, M. (1994). Qualitative data analysis: An expanded sourcebook: sage.

Mitchell-Weaver, C., \& Manning, B. (1991). Public Private Partnership in third World development: a conceptual overview. Studies in Comparative International Development, 26(4), 45-67.

Mouraviev, N. (2013). An analysis of governance policy and practice in public-private partnerships in transitional economies: A case study of Kazakhstan and Russia. (Doctor of Philosophy Thesis), University of Northampton,

Opawole, A., \& Jagboro, G. O. (2017). Factors affecting the performance of private party in concessionbased PPP projects in Nigeria. Journal of Engineering, Design and Technology, 15(1), 44-57.

Osei-Kyei, R., \& Chan, A. P. C. (2017). Factors attracting private sector investments in public-private partnerships in developing countries A survey of international experts. Journal of Financial Management of Property and Construction, 22(1), 92-111. doi:10.1108/jfmpc-06-2016-0026

Peters, B. G. (2000). Policy instruments and public management: bridging the gaps. Journal of Public Administration Research and Theory, 10(1), 35-47.

Pinkse, J., \& Kolk, A. (2012). Addressing the Climate Change-Sustainable Development Nexus: The Role of Multistakeholder Partnerships. Business \& Society, 51(1), 176-210. doi:10.1177/0007650311427426

Pittz, T. G., \& Adler, T. (2016). An exemplar of open strategy: decision-making within multi-sector collaborations. Management Decision, 54(7), 1595-1614. doi:10.1108/md-04-2015-0153

Public Enterprises Reform and Divestiture Act, Parliament of Uganda, Pub. L. No. 98 (1993).

Reeves, E. (2013). The not so good, the bad and the ugly: over twelve years of PPP in Ireland. Local Government Studies, 39(3), 375-395.

Reeves, E., \& Ryan, J. (2007). Piloting public-private partnerships: Expensive lessons from Ireland's schools' sector. Public Money and Management, 27(5), 331-338.

Simo, G., \& Bies, A. L. (2007). The role of nonprofits in disaster response: An expanded model of crosssector collaboration. Public administration review, 67, 125-142.

Slater, R. (2001). Local government partnerships in urban management: the case of South Asia. Local Government Studies, 27(3), 79-96.

Stafford, A., \& Stapleton, P. (2017). Examining the Use of Corporate Governance Mechanisms in PublicPrivate Partnerships: Why Do They Not Deliver Public Accountability? Australian Journal of Public Administration, 76(3), 378-391. doi:10.1111/1467-8500.12237

Steinmo, S. (2008). Historical institutionalism. Approaches and methodologies in the social sciences: $A$ pluralist perspective, 118-138.

Szmigiel-Rawska, K. (2016). Sustainability of cross-border cooperation: PHARE CBC partnership development paths. European Urban and Regional Studies, 23(3), 513-526. doi:10.1177/0969776414526734 
Tangri, R. K. (1999). The politics of patronage in Africa: parastatals, privatization, and private enterprise in Africa: Africa World Press.

Thelen, K. (1999). Historical institutionalism in comparative politics. Annual review of political science, 2(1), 369-404.

Thelen, K. (2002). The explanatory power of historical institutionalism. Mayntz, Renate (Hg.): AkteureMechanismen-Modelle. Zur Theoriefähigkeit makro-sozialer Analysen. Frankfurt, New York, 91107.

Uganda News Releases. (2015). Privatisation: Explaining Museveni's U-turn. Retrieved from https://www.ugandanewsreleases.com/\%EF\%BB\%BFprivatisation-explaining-musevenis-u-turn/

Van den Hurk, M., \& Verhoest, K. (2015). The governance of public-private partnerships in sports infrastructure: Interfering complexities in Belgium. International journal of project management, 33(1), 201-211.

Velotti, L., Botti, A., \& Vesci, M. (2012). PUBLIC-PRIVATE PARTNERSHIPS AND NETWORK GOVERNANCE What Are the Challenges? Public Performance \& Management Review, 36(2), 340-365. doi:10.2753/pmr1530-9576360209

Vurro, C., Dacin, M. T., \& Perrini, F. (2010). Institutional Antecedents of Partnering for Social Change: How Institutional Logics Shape Cross-Sector Social Partnerships. Journal of Business Ethics, 94, 39-53. doi:10.1007/s10551-011-0778-0

Ward, S., \& Chapman, C. (2008). Stakeholders and uncertainty management in projects. Construction Management and economics, 26(6), 563-577.

Weihe, G. (2006). Public-Private Partnerships: Addressing a Nebulous Concept. Paper presented at the 10th International Research Symposium on Public Management, Glasgow Caledonian University, Scotland.

Wettenhall, R. (2010). Mixes and Partnerships thruogh time. In G. A. Hodge, C. Greve, \& A. E. Boardman (Eds.), International Handbook on Public-Private Partnerships. United Kingdom: Edward Elgar Publishing Limited.

World Bank. (2017). Infrastructure finance deficit: Can public-private partnerships fill the gap? Retrieved from Kampala:

World Bank. (2018). 2017 Energy Sector : Private Participation in Infrastructure. Retrieved from Washington DC: https://openknowledge.worldbank.org/handle/10986/31037

World Bank. (2019). The Private Participation in Infrastructure (PPI) Project Database has data. Retrieved from https://ppi.worldbank.org/en/ppidata

Yin, R. K. (2011). Applications of case study research: sage.

Yuan, J., Skibniewski, M. J., Li, Q., \& Zheng, L. (2009). Performance objectives selection model in publicprivate partnership projects based on the perspective of stakeholders. Journal of Management in Engineering, 26(2), 89-104. 
Figure 1: Structure of Uganda's Electricity Sector

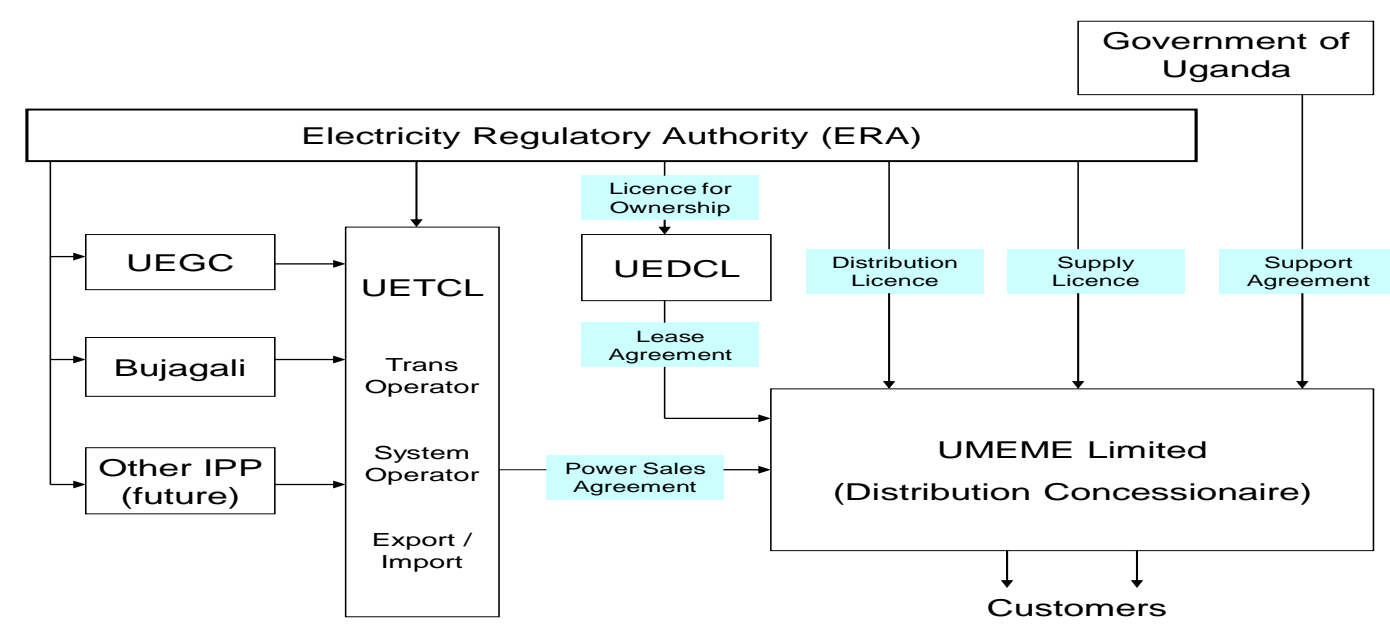

